\title{
БІОХІМІЧНИЙ ПРОФІЛЬ ТА АКТИВНІСТЬ ЕНЗИМІВ СИРОВАТКИ КРОВІ КУРЕЙ ЗА ВПЛИВУ ВЕЛИЧИНИ УГРУПУВАННЯ
}

\author{
Осадча Юлія Василівна \\ кандидат сільськогосподарських наук, доцент \\ Національний університет біоресурсів і природокористування України \\ ORCID: 0000-0003-4126-2456 \\ E-mail: seledat@ukr.net
}

Представлено результати вивчення фізіологічних змін в організмі курей, зумовлених зміною величини їх угрупування на основі аналізу параметрів клінічної біохімії сироватки крові. Для цього у умовах сучасного комплексу з виробництва харчових яєць сформували 4 групи курей, кожну з яких утримували в окремому пташнику-аналогу за площею та устаткуванням, обладнаному 12-ярусними клітковими батареями, розмір кліток в яких різнився. Величина угрупування курей у кожній клітиі 1-ї групи складала 93 гол., 2-ї - 52 гол., 3-ї - 17 гол. та 4-ї - 9 гол. У віці 52 тижні у курей кожної групи відбирали по 30 проб крові та визначали біохімічні параметри та активність ензимів в її сироватці. Виявлено, що зменшення величини угрупування курей за утримання їх в клітках багатоярусних батарей від 93 до 52 гол супроводжується лише підвищення активності лактатдегідрогенази на 14,4 \% в межах фізіологічної норми. За зменшення величини угрупування від 93 до 17 голів спостерігається підвищення рівня глюкози на 7,5 \% та фоссрору - на 89,2 \% в межах фрізіологічної норми, зниження співвідношення кальцію та фоссфору на 30,0 \%, підвищення активності аспартатамінотрансфрерази на 17,7 \%, лужної фосффатази - на 94,4 \%, гамма-глутамілтрансферази - на 17,8 \% та лактатдегідрогенази - на 27,9 \%. Зменшення величини угрупування курей від 93 до 9 гол супроводжується розвитком у них хронічного стресу, який проявлявся гіперелікемією з підвищенні рівня глюкози на 61,3 \%, креатиніну - на 7,8 \%, зниженням співвідношення кальцію та фосффору на 76,5 \%, що підтверджується підвищенням активності лужної фосффатази на 107,4 \%, а також аспартатамінотранссферази - на 25,1 \%, лактатдегідрогенази - на 59,6 \% та гамма-глутамілтрансфрерази - на 25,7 \%. Таким чином, основні наслідки хронічного стресу спричиненого утриманням курей угрупуваннями малих розмірів, відображаються в біохімічних параметрах сироватки їх крові, а саме в підвищенні вмісту глюкози, креатиніну, активності ензимів, а також порушенні співвідношення кальцію та фоссрору.

Ключові слова: кури-несучки, шільність утримання, хронічний стрес, глюкоза, креатинін, активність ензимів

DOI: https://doi.org/10.32845/bsnau.lvst.2021.4.19

Величина угрупування курей чинить тиск на основні структури їх мозку, що зумовлено підвищеними вимогами до птиці, яка живе у відносно великих, складних та динамічних соціальних організаціях (Croney \& Newberry, 2007). Ці вимоги стосуються здебільшого конкуренції за їжу або доступ до інших цінних ресурсів. Варіації розміру угрупування в природних популяціях саморегулюються, а в умовах промислового утримання кури не мають можливості покинути групову обстановку, в результаті чого утворюються посилені агресивні взаємодії, які можуть сприяти деспотичній поведінці (Bas Rodenburg \& Koene, 2007). Однак останні дослідження показують, що соціальна поведінка курей не обмежується лише формуванням ієрархії, і вона набагато пластичніша та динамічніша, ніж вважалося раніше. Ця поведінкова пластичність дозволяє птиці змінювати стратегії та легше пристосовуватися до різних технологічних (соціальних та фізичних) умов у межах обмеженого угрупування (Estevez et al., 2007).

Збільшення величини угрупування курей (більше 10 голів) за їх утримання в клітках багатоярусних батарей дослідники асоціюють із зниженням збереженості поголів'я та погіршенням продуктивності, що є проявами стресових станів (Appleby, 1998; Appleby et al., 2002; Hetland et al., 2004). Також $є$ повідомлення про те, що утримання курей середніми за величиною угрупуваннями (близько 30 голів) може провокувати у них соціальний стрес, який також супроводжуються зниженням продуктивності, оскільки розмір такої групи занадто великий, щоб скласти стабільну ієрархію, але замалий для толерантної соціальної системи (Keeling et al., 2003; Guo et al., 2012).

Однак, вплив величини угрупування курей на їх ор-

ганізм, за кліткового утримання з однаковою забезпеченістю площею, вивчався в основному на невеликих групах птиці, розміром до 10 голів (Abrahamsson \& Tauson, 1997; Appleby, 1998; Vits et al., 2005) або ж в дослідах використовували клітки різних конструкцій та виробників, що унеможливлює їх адекватне порівняння (Weimer et al., 2018).

Відомо, що під час стресу у курей напружується діяльність всіх систем організму, яка спрямовується на самозахист і пристосування до нових умов існування (Olubodun et al., 2015; Infante et al., 2017; Shevchuk et al., 2018). Для діагностики стресу, а також характеристики процесів адаптації в організмі курей зазвичай використовують лейкоцитарну формулу (Jiang et al., 2017; Liew \& Kubes, 2019) та концентрацію гормонів в крові (Scanes, 2016; Weimer et al., 2018). I лише останнім часом у птиці почали активно використовувати деякі біохімічні параметри сироватки крові (Nwaigwe et al., 2020; Ruiz-Jimenez et al., 2021), які, на відміну від лейкоцитарної формули та гормонального статусу, дозволяють описати загальний фізіологічний стан організму, процеси адаптації (Kraus et al., 2021) та діагностувати метаболічні порушення органів та тканин (Koronowicz et al., 2016).

Виходячи 3 вищенаведеного, метою роботи було вивчення фізіологічних змін в організмі курей, зумовлених зміною величини їх угрупування на основі аналізу параметрів клінічної біохімії сироватки крові.

Матеріал та методи досліджень. В якості об'єкта досліджень використовували яєчних курей промислового стада кросу «Hy-Line W-36». Досліди з експериментальними тваринами проводили відповідно до правил Європейської конвенції про захист хребетних тварин (Офіційний вісник

Вісник Сумського національного аграрного університету 
Європейського Союзу L276/33, 2010).

В умовах сучасного комплексу з виробництва харчових яєць сформували 4 групи курей, кожну з яких утримували в окремому пташнику-аналогу за площею (2915 м²), обладнаному 12-ярусними клітковими батареями «Big Dutchman» (Німеччина), розмір кліток в яких різнився. Залежно від розміру кліток, за однакової щільності посадки $(23,0$ гол./м²), поголів'я курей у них було різним. Величина угрупування курей у кожній клітці 1-ї групи (клітка 362×112,0 см) складала 93 гол., 2-ї групи (клітка 360×62,55 cм) - 52 гол., 3-ї (клітка $120 \times 62,55$ см) - 17 гол. та 4-ї (клітка $70 \times 56$ см) - 9 гол. (табл. 1).

Упродовж досліду курей забезпечували питною водою, повнораціонними комбікормами однакового складу та утримували згідно з вимогами (ВНТП-АПК-04.05.).

Біохімічні показники та активність ензимів сироватки крові курей, а саме вміст загального білку, альбуміну, глюкози, креатиніну, сичовини, білірубіну, холестерину, фосфору, кальцію, активність аланінамінотранферази (АЛТ), аспартатамінотрансферази (АСТ), гамма-глутамілтрансферази (ГГТ), лужної фосфатази та лактатдегідрогенази (ЛДГ), визначали на біохімічному аналізаторі BioChem FC-360 (Hightechnology Inc.) у лабораторії «Бальд» (сертифікат №LB/02/2016). Для цього відбирали по 30 проб крові у несучок кожної групи у віці 18 тижнів (на початку досліджень) та у 52 тижні. Відбирали по 1,0-1,5 мл крові з підкрильцевої вени у пробірку з EDTA.

Отримані цифрові результати опрацьовували методами варіаційної статистики. Достовірність відмінностей між середніми величинами визначали за t-критерієм Ст'юдента, різниці вважали достовірними за $р<0,05$.

Схема досліду

Таблиця 1

\begin{tabular}{|c|c|c|c|c|}
\hline \multirow{2}{*}{ Характеристика } & \multicolumn{4}{|c|}{ Група курей } \\
\hline & 1 & 2 & 3 & 4 \\
\hline Кількість ярусів у пташнику & \multicolumn{4}{|c|}{12} \\
\hline Кількість кліток & 4704 & 6048 & 18144 & 30912 \\
\hline Кількість голів у клітці / величина угрупування & 93 & 52 & 17 & 9 \\
\hline Кількість голів у групі & 437472 & 314496 & 308448 & 278208 \\
\hline Щільність посадки, гол./м² & \multicolumn{4}{|c|}{23,0} \\
\hline Забезпеченість площею, см²/гол & 436,0 & 433,0 & 441,5 & 435,6 \\
\hline $\begin{array}{l}\text { Розміри клітки, см: } \\
\text { - довжина } \\
\text { - глибина }\end{array}$ & $\begin{array}{c}362 \\
112,0\end{array}$ & $\begin{array}{c}360 \\
62,55\end{array}$ & $\begin{array}{c}120 \\
62,55\end{array}$ & $\begin{array}{l}70 \\
56\end{array}$ \\
\hline Площа клітки, см² & 40544 & 22518 & 7506 & 3920 \\
\hline Кількість ніпелів у клітці, шт. & 12 & 17 & 12 & 1,5 \\
\hline Фронт годівлі, см & 7,8 & 6,9 & 7,1 & 7,8 \\
\hline Площа пташника, см² & \multicolumn{4}{|c|}{2915} \\
\hline
\end{tabular}

Результати досліджень та їх обговорення. Виявлено, що зміна розміру групи курей під час їх утримання в клітках багатоярусних батарей не позначалось на вмісті у сироватці їх крові загального білку, альбуміну, сечовини, холестерину, білірубіну та кальцію (табл. 2), які знаходились в межах фізіологічної норми.

Таблиця 2

Біохімічний профіль сироватки крові курей-несучок

\begin{tabular}{|c|c|c|c|c|c|}
\hline \multirow{2}{*}{ Показник } & \multicolumn{4}{|c|}{ Група } & \multirow{2}{*}{$\begin{array}{l}\text { Peф. } \\
\text { знач. }\end{array}$} \\
\hline & 1 & 2 & 3 & 4 & \\
\hline Загальний білок, г/л & $58,7 \pm 0,55$ & $57,0 \pm 0,61$ & $55,7 \pm 0,57$ & $57,2 \pm 0,46$ & $37,8-59,0$ \\
\hline Альбумін, г/л & $19,1 \pm 0,19$ & $19,8 \pm 0,11$ & $19,2 \pm 0,11$ & $18,8 \pm 0,20$ & $15,0-25,0$ \\
\hline Глюкоза, ммоль/л & $10,6 \pm 0,26$ & $10,3 \pm 0,12$ & $11,4 \pm 0,29^{* * 0 \prime}$ & $17,1 \pm 0,54^{* * 000+1}$ & $10,0-16,5$ \\
\hline Креатинін, мкмоль/л & $25,8 \pm 0,66$ & $26,1 \pm 0,33$ & $26,6 \pm 0,25$ & $27,8 \pm 0,36^{* 00 \mathrm{II}}$ & $22,0-27,0$ \\
\hline Сечовина, ммоль/л & $1,26 \pm 0,104$ & $1,00 \pm 0,026$ & $1,42 \pm 0,024$ & $0,74 \pm 0,025$ & $0,7-2,4$ \\
\hline $\begin{array}{l}\text { Білірубін, мкмоль/л } \\
\text { - загальний } \\
\text { - прямий } \\
\text { - непрямий }\end{array}$ & $\begin{array}{l}1,20 \pm 0,094 \\
0,20 \pm 0,047 \\
1,00 \pm 0,070\end{array}$ & $\begin{array}{l}1,24 \pm 0,030 \\
0,16 \pm 0,009 \\
1,08 \pm 0,024\end{array}$ & $\begin{array}{l}1,36 \pm 0,076 \\
0,34 \pm 0,022 \\
1,02 \pm 0,020\end{array}$ & $\begin{array}{l}1,68 \pm 0,147 \\
0,26 \pm 0,028 \\
1,42 \pm 0,146\end{array}$ & $\begin{array}{l}1,7 \\
0,5 \\
- \\
\end{array}$ \\
\hline Холестерин, ммоль/л & $3,9 \pm 0,19$ & $3,56 \pm 0,118$ & $3,26 \pm 0,067$ & $3,34 \pm 0,223$ & $2,0-4,0$ \\
\hline Фоссрор, ммоль/л & $1,48 \pm 0,047$ & $1,38 \pm 0,041$ & $2,16 \pm 0,049^{* * 001}$ & $2,70 \pm 0,022^{* * 00 !}$ & $1,15-2,2$ \\
\hline Кальцій, ммоль/л & $4,30 \pm 0,136$ & $4,16 \pm 0,075$ & $4,38 \pm 0,029$ & $4,42 \pm 0,071$ & $2,8-4,6$ \\
\hline Кальцій/форффор & $3,0 \pm 0,15$ & $3,1 \pm 0,11$ & $2,1 \pm 0,07^{* * 0 \circ}$ & $1,7 \pm 0,06^{* * 001}$ & $3-3,8: 1$ \\
\hline
\end{tabular}

Примітки: " $p<0,01,{ }^{* *} p<0,001$ - порівняно з першою групою; ${ }^{\circ} p<0,01,{ }^{\circ}{ }^{\circ} p<0,001-$ порівняно з другою групою; 'p<0,05, "p<0,01, "'p<0,001 - порівняно з третьою групою; *Ресрерентні значення за Насоновим I.B. (Nasonov et al., 2014).

Вміст глюкози та креатиніну в сироватці крові курей 1-3 груп, тобто за розміру групи від 93 до 17 гол., знаходився в межах фрізіологічної норми. Найвищий вміст глюкози виявлений у курей 4-ї групи з перевищенням фізіологічної норми на 3,6 \%. Водночас, вміст глюкози в сироватці крові курей 4-ї групи був вищим на 61,3\% (p<0,001) порівняно 3 1 -ю групою, на 66,0 \% (p<0,001) і 50,0\% (p<0,001) порівняно з 2-ю та 3-ю групами відповідно. Вміст глюкози у сироватці крові курей 3-ї групи був вищим на 7,5 \% (p<0,01) і 10,7\% ( $p<0,001)$ порівняно з 1-ю та 2-ю групами відповідно, різниця між якими складала лише 0,3 ммоль/л і статистично не підтвердилась. Тоді як вміст креатиніну в сироватці крові курей 4-ї групи на 3,0 \% перевищував верхню межу фізіологічної норми та був вищим на 7,8 \% $(p<0,01)$ порівняно 3 1-ю гру- 
пою та на 6,5 \% (p<0,001) і 4,5 \% (p<0,001) порівняно з 2-ю та 3-ю групами відповідно.

Слід також відзначити перевищення фізіологічної норми за вмістом фосфору в сироватці крові курей 4-ї групи на 22,7\%. Водночас вміст фосфору у них був вищим на $82,4 \%$ (p<0,001) порівняно 3 1-ю групою та на 95,7 \% ( $p<0,001)$ і 25,0 \% (p<0,001) порівняно з 2-ю та 3-ю групами відповідно. Вміст фоссрору у сироватці крові курей 3-ї групи був вищим на 89,2\% (p<0,001) і 56,5\% (p<0,001) порівняно з 1-ю та 2-ю групами відповідно, різниця між якими складала лише 0,1 ммоль/л і статистично не підтвердилась.

Співвідношення кальцію і фоссрору у сироватці крові курей 1-ї та 2-ї групи знаходилось в межах фізіологічної норми, а у 3-ї та 4-ї - не досягало нормативного рівня і знижувалось із зменшенням величини угрупування. Найнижче співвідношення кальцію та фосфору і, відповідно, найбільше відхилення від фізіологічної норми, - на 43,3 \%, виявлено у курей 4-ї групи, що на 76,5\% (p<0,001) нижче порівняно 31 ю групою та на 82,4 \% (p<0,001) і 23,5% (p<0,05) порівняно 3 2-ю та 3-ю групами відповідно. У курей 3-ї групи співвідношення кальцію та фосфору не досягало фізіологічної норми на $30,0 \%$ та було нижчим на $30,0 \%$ (p<0,001) та $32,3 \%$ ( $p<0,001)$ порівняно з 1-ю та 2-ю групами відповідно.

Порушення обміну особливо важливих для несучок макроелементів - кальцію і фосфору, підтверджує зміна у сироватці їх крові активності лужної фоссфатази (табл.3 ). Спостерігається підвищення активності лужної фосфатази із зменшенням величини угрупування курей, а саме у курей 34 груп, тобто за зменшення розміру групи до 17 гол. - на 17,6 \% і до 9 гол. - на 25,5 \%. Найвища її активність виявлена у курей 4-ї групи - на 107,4\% ( $<<0,001)$ та 80,3 \% ( $<<0,001)$ порівняно з 1-ю та 2-ю групами відповідно, тоді як різниця з 3-ю групою складала 6,7 \% та статистично не підтвердилась. У курей 3-ї групи активність лужної фосфатази була вищою на 94,4 \% (p<0,001) та 69,0 \% (p<0,001) порівняно з 1-ю та 2-ю групами відповідно. Різниця між 1-ю та 2-ю групами складала лише 15,0 \% і статистично не підтвердилась.

Активність ензимів сироватки крові курей-несучок

\begin{tabular}{|c|c|c|c|c|c|}
\hline \multirow{2}{*}{$\begin{array}{c}\text { Показник, } \\
\text { од/л }\end{array}$} & \multicolumn{4}{|c|}{ Група } & \multirow{2}{*}{$\begin{array}{c}\text { Реф. } \\
\text { знач.* }\end{array}$} \\
\hline & 1 & 2 & 3 & 4 & \\
\hline АЛТ & $0,9 \pm 0,10$ & $0,8 \pm 0,13$ & $0,6 \pm 0,09$ & $0,4 \pm 0,09$ & $13,0-26,5$ \\
\hline ACT & $196,7 \pm 5,19$ & $201,8 \pm 4,85$ & $231,6 \pm 4,36^{* * * 0 \circ \circ}$ & $246,0 \pm 5,77^{* * * 001}$ & $125-210$ \\
\hline ГГТ & $25,3 \pm 0,97$ & $25,6 \pm 0,54$ & $29,8 \pm 0,36^{* \star * 000}$ & $31,8 \pm 0,87^{* * * 0001}$ & - \\
\hline$Л \Phi$ & $502,1 \pm 13,18$ & $577,6 \pm 27,05$ & $976,0 \pm 30,22^{* * * 00}$ & $1041,6 \pm 44,15^{* * 000}$ & $350-830$ \\
\hline ЛДГ & $1471,1 \pm 83,02$ & $1682,4 \pm 66,86^{*}$ & $1881,8 \pm 67,36^{* * * 0}$ & $2347,8 \pm 53,75^{* * 0000 \mathrm{~m}}$ & $636-1960$ \\
\hline
\end{tabular}

"p<0,01, "'p<0,001 - порівняно з третьою групою; *Референтні значення за Насоновим I.B. (Nasonov et al., 2014)

Із зменшенням величини угрупування курей збільшувалась також активність аспартатамінотрансферази (АСТ). Перевищення фізіологічної норми спостерігалось вже у курей 3-ї та 4-ї груп, тобто за зменшення розміру групи до 17 гол. на 10,3 \% і до 9 гол. - на 17,1\%. Активність АСТ у курей 4-ї групи підвищилась на 25,1\% (p<0,001) порівняно з 1-ю групою та на 21,9\% $(p<0,001)$ і 6,2 \% (p<0,05) порівняно з 2-ю та 3-ю групами відповідно. Водночас, активність АСТ у курей 3-ї групи була вищою на 17,7 \% (p<0,001) та 14,8 \% ( $p<0,001)$ порівняно з 1-ю та 2-ю групами відповідно. Різниця між 1-ю та 2-ю групами складала лише 2,6 \% та статистично не підтвердилась.

Активність гамма-глутамілтрансферази (ГГТ) у сироватці крові курей підвищувалась із зменшенням величини угрупування. Найвищою активність ГГТ була у курей 4-ї групи і перевищувала на 25,7 \% (p<0,001) показники 1-ї групи та на 24,2 \% ( $<<0,001)$ і 6,7 \% (p<0,05) - 2-ї та 3-ї груп відповідно. Водночас, активність ГГТ у курей 1-ї та 2-ї груп була майже однаковою з різницею лише 0,3 од/л без статистичного підтвердження. У курей 3-ї групи активність ГГТ була вищою на $17,8 \%(p<0,001)$ та $16,4 \%(p<0,001)$ порівняно з 1-ю та 2-ю групами відповідно. Таким чином, збільшення активності ГГТ у сироватці крові курей спостерігалося вже за зменшення розміру групи до 17 голів і надалі зростало пропорційно зменшенню розміру групи.

Зменшення величини угрупування курей супроводжувалось збільшенням активності лактатдегідрогенази (ЛДГ). Перевищення фізіологічної норми спостерігалось у курей 4-ї групи, тобто за зменшення розміру групи до 9 гол. - на 19,8 \%. Водночас, активність ЛДГ у сироватці крові курей 4-ї групи була вищою на 59,6 \% (p<0,001) порівняно з 1-ю групою та на
$39,6 \%$ (p<0,001) і 24,8 \% (p<0,001) порівняно з 2-ю та 3-ю групами відповідно. У сироватці крові курей 2-ї групи активність ЛДГ була вищою на 14,4 \% (p<0,05) порівняно з 1-ю групою, а 3-ї групи - на 27,9 \% (p<0,001) та 11,9 \% (p<0,05) порівняно 3 1-ю та 2-ю групами відповідно.

Висновки. Зменшення величини угрупування курей за утримання їх в клітках багатоярусних батарей від 93 до 52 гол супроводжується лише підвищення активності лактатдегідрогенази на 14,4 \% в межах фізіологічної норми. Тоді як за зменшення величини угрупування від 93 до 17 голів спостерігається підвищення рівня глюкози на 7,5\% та фоосфору - на 89,2 \% в межах фізіологічної норми, зниження співвідношення кальцію та фосфору на 30,0 \% (30 \% < норми), підвищення активності аспартатамінотрансферази на 17,7 \% (10,3% > норми), лужної фосфратази - на 94,4 \% (17,6 \% > норми), гамма-глутамілтрансферази - на 17,8 \% та лактатдегідрогенази - на 27,9 \% в межах фізіологічної норми. Зменшення величини угрупування від 93 до 9 гол супроводжується розвитком у курей хронічного стресу, який проявлявся гіперглікемією 3 підвищенні рівня глюкози на 61,3\% (3,6 \% > норми), креатиніну - на 7,8 \% (3,0 \% > норми), зниженням співвідношення кальцію та фросфрору на 76,5 \% (43,3 \% < норми), що підтверджується підвищенням активності лужної фросфатази на 107,4 $\%$ (25,5 \% > норми), а також аспартатамінотрансферази - на $25,1 \%$ (25,5 \% > норми), лактатдегідрогенази - на 59,6 \% (19,8 \% > норми) та гамма-глутамілтрансферази - на 25,7 \%. Таким чином, основні наслідки хронічного стресу спричиненого утриманням курей угрупуваннями малих розмірів, відображаються в біохімічних параметрах сироватки їх крові, а саме в підвищенні вмісту глюкози, креатиніну, активності ензимів, а також порушенні співвідношення кальцію та фосфору. 


\section{Список використаної літератури:}

1. Abrahamsson P., Tauson R. Effects of group size on performance, health and birds' use of facilities in furnished cages for laying hens. Acta Agriculturae Scandinavica - Section A: Animal Science. 1997. Vol. 47. P. 254-260. DOl:10.1080/09064709709362394

2. Appleby M.C. Modification of laying hen cages to improve behavior. Poultry Science. 1998. Vol. 77. P. 1828-1832. DOI:10.1093/ps/77.12.1828

3. Appleby M.C., Walker A.W., Nicol C.J., Lindberg A.C., Freire R., Hughes B.O., Elson H.A. Development of furnished cages for laying hens. British Poultry Science. 2002. Vol. 43. P. 489-500. DOI:10.1080/0007166022000004390

4. Bas Rodenburg T., Koene P. The impact of group size on damaging behaviours, aggression, fear and stress in farm animals. Applied Animal Behaviour Science. 2007. Vol. 103(3-4). P. 205-214. DOI:10.1016/j.applanim.2006.05.024

5. Croney C.C., Newberry R.C. Group size and cognitive processes. Applied Animal Behaviour Science. 2007. Vol. 103(3-4). P. 215-228. DOl:10.1016/j.applanim.2006.05.023

6. Estevez I., Andersen I.-L., Nevdal E. Group size, density and social dynamics in farm animals. Applied Animal Behaviour Science. 2007. Vol. 103(3-4). P. 185-204. DOI:10.1016/j.applanim.2006.05.025

7. Guo Y.Y., Song Z.G., Jiao H.C., Song Q.Q., Lin H. The effect of group size and stocking density on the welfare and performance of hens housed in furnished cages during summer. Animal Welfare. 2012. Vol. 21. P. 41-49. DOI:10.7120/096272812799129501

8. Hetland H., Moe R.O., Tauson R., Lervik S., Svihus B. Effect of includingwhole oats into pellets on performance and plumage condition in laying henshoused in conventional and furnished cages. Acta Agriculturae Scandinavica - Section A: Animal Science. 2004. Vol. 54. P. 206-212. DOI:10.1080/09064700410010026

9. Infante M., Armani A., Mammi C., Fabbri A., Caprio, M. Impact of adrenal steroids on regulation of adipose tissue. Comprehensive Physiology. 2017. Vol. 7(4). P. 1425-1447. DOl:10.1002/cphy.c160037

10. Jiang W., Li Y., Sun J., Li L., Li J.W., Zhang C., Huang C., Yang J., Kong G.Y., Li Z.F. Spleen contributes to restraint stress induced changes in blood leukocytes distribution. Scientific Reports. 2017. Vol. 27(1). P. 6501. DOI:10.1038/s41598-01706956-9

11. Keeling L.J., Estevez I., Newberry R.C., Correia M.G. Production-relatedtraits of layers reared in different sized flocks: The concept of problematicintermediate group sizes. Poultry Science. 2003. Vol. 82. P. 1393-1396. DOI:10.1093/ps/82.9.1393

12. Koronowicz A.A., Banks P., Szymczyk B., Leszczyńska T., Master A., Piasna E., Szczepański W., Domagała D., Kopeć A., Piatkowska E., Laidler P. Dietary conjugated linoleic acid affects blood parameters, liver morphology and expression of selected hepatic genes in laying hens. British Poultry Science. 2016. Vol. 57(5). P. 663-673. DOI:10.1080/00071668.2016.1192280

13. Kraus A., Zita L., Krunt O., Härtlová H., Chmelíková E. Determination of selected biochemical parameters in blood serum and egg quality of Czech and Slovak native hens depending on the housing system and hen age. Poultry Science. 2021. Vol. 100 (2). P. 1142-1153. DOI:10.1016/j.psj.2020.10.039

14. Liew P.X., Kubes P. The Neutrophil's Role During Health and Disease. Physiological Reviews. 2019. Vol. 99(2). P. 12231248. DOI:10.1152/physrev.00012.2018

15. Nwaigwe C.U., Ihedioha J.I., Shoyinka S.V., Nwaigwe C.O. Evaluation of the hematological and clinical biochemical markers of stress in broiler chickens. Veterinary World. 2020. Vol. 13(10). P. 2294-2300. DOl:10.14202/vetworld.2020.2294-2300

16. Olubodun J., Zulkifli I., Hair-Bejo M., Kasim A., Soleimani A.F. Physiological response of glutamine and glutamic acid supplemented broiler chickens to heat stress. European Poultry Science. 2015. Vol. 79. P. 1-12. DOI:10.1399/eps.2015.87

17. Ruiz-Jimenez F., Gruber E., Correa M., Crespo R. Comparison of portable and conventional laboratory analyzers for biochemical tests in chickens. Poultry Science. 2021. Vol. 100(2). P. 746-754. DOI:10.1016/j.psj.2020.11.060

18. Scanes C.G. Biology of stress in poultry with emphasis on glucocorticoids and the heterophil to lymphocyte ratio. Poultry Science. 2016. Vol. 95(9). P. 2208-2215. DOI:10.3382/ps/pew137

19. Shevchuk M., Stoyanovskyy V., Kolomiiets I. Technological stress in poultry. Scientific Messenger of LNU of Veterinary Medicine and Biotechnologies. Series: Veterinary Sciences. 2018. Vol. 20(88). P. 63-68. DOI:10.32718/nvlvet8811.

20. Vits A., Weitzenburger D., Hamann H., Distl O. Production, egg quality,bone strength, claw length, and keel bone deformities of laying hens housed infurnished cages with different group sizes. Poultry Science. 2005. Vol. 84. P. 1511-1519. DOI:10.1093/ps/84.10.1511

21. Weimer S.L., Wideman R.F., Scanes C.G., Mauromoustakos A., Christensen K.D., Vizzier-Thaxton Y. An evaluation of methods for measuring stress in broiler chickens. Poultry Science. 2018. Vol. 97(10). P. 3381-3389. DOI:10.3382/ps/pey204

\section{References:}

1. Abrahamsson, P., \& Tauson, R. (1997). Effects of group size on performance, health and birds' use of facilities in furnished cages for laying hens. Acta Agriculturae Scandinavica - Section A: Animal Science, 47, 254-260. DOI:10.1080/09064709709362394

2. Appleby, M.C. (1998). Modification of laying hen cages to improve behavior. Poultry Science, 77, 1828-1832. DOI:10.1093/ps/77.12.1828

3. Appleby, M.C., Walker, A.W., Nicol, C.J., Lindberg, A.C., Freire, R., Hughes, B.O., \& Elson, H.A. (2002). Development of furnished cages for laying hens. British Poultry Science, 43, 489-500. DOI:10.1080/0007166022000004390

4. Bas Rodenburg, T., \& Koene, P. (2007). The impact of group size on damaging behaviours, aggression, fear and stress in farm animals. Applied Animal Behaviour Science, 103(3-4), 205-214. DOI:10.1016/j.applanim.2006.05.024

5. Croney, C.C., \& Newberry, R.C. (2007). Group size and cognitive processes. Applied Animal Behaviour Science, 103(3- 
4), 215-228. DOI:10.1016/j.applanim.2006.05.023

6. Estevez, I., Andersen, I.-L., \& Nevdal, E. (2007). Group size, density and social dynamics in farm animals. Applied Animal Behaviour Science, 103(3-4), 185-204. DOI:10.1016/j.applanim.2006.05.025

7. Guo, Y.Y., Song, Z.G., Jiao, H.C., Song, Q.Q., \& Lin, H. (2012). The effect of group size and stocking density on the welfare and performance of hens housed in furnished cages during summer. Animal Welfare, 21, 41-49. DOI:10.7120/096272812799129501

8. Hetland, H., Moe, R.O., Tauson, R., Lervik, S., \& Svihus, B. (2004). Effect of includingwhole oats into pellets on performance and plumage condition in laying henshoused in conventional and furnished cages. Acta Agriculturae Scandinavica - Section A: Animal Science, 54, 206-212. DOI:10.1080/09064700410010026

9. Infante, M., Armani, A., Mammi, C., Fabbri, A., \& Caprio, M. (2017). Impact of adrenal steroids on regulation of adipose tissue. Comprehensive Physiology, 7(4), 1425-1447. DOI: 10.1002/cphy.c160037

10. Jiang, W., Li, Y., Sun, J., Li, L., Li, J.W., Zhang, C., Huang, C., Yang, J., Kong, G.Y., \& Li, Z.F. (2017). Spleen contributes to restraint stress induced changes in blood leukocytes distribution. Scientific Reports, 27(1), 6501. DOI: 10.1038/s41598-017-06956-9

11. Keeling, L.J., Estevez, I., Newberry, R.C., \& Correia, M.G. (2003). Production-relatedtraits of layers reared in different sized flocks: The concept of problematicintermediate group sizes. Poultry Science, 82, 1393-1396. DOI:10.1093/ps/82.9.1393

12. Koronowicz, A.A., Banks, P., Szymczyk, B., Leszczyńska, T., Master, A., Piasna, E., Szczepański, W., Domagała, D., Kopeć, A., Piątkowska, E., \& Laidler, P. (2016). Dietary conjugated linoleic acid affects blood parameters, liver morphology and expression of selected hepatic genes in laying hens. British Poultry Science, 57(5), 663-673. DOI:10.1080/00071668.2016.1192280

13. Kraus, A., Zita, L., Krunt, O., Härtlová, H., \& Chmelíková, E. (2021). Determination of selected biochemical parameters in blood serum and egg quality of Czech and Slovak native hens depending on the housing system and hen age. Poultry Science, 100 (2), 1142-1153. DOI:10.1016/j.psj.2020.10.039

14. Liew, P.X., \& Kubes, P. (2019). The Neutrophil's Role During Health and Disease. Physiological Reviews, 99(2), 12231248. DOI:10.1152/physrev.00012.2018

15. Nwaigwe, C.U., Ihedioha, J.I., Shoyinka, S.V., \& Nwaigwe, C.O. (2020). Evaluation of the hematological and clinical biochemical markers of stress in broiler chickens. Veterinary World, 13(10), 2294-2300. DOI:10.14202/vetworld.2020.2294-2300

16. Olubodun, J., Zulkifli, I., Hair-Bejo, M., Kasim, A., \& Soleimani, A.F. (2015). Physiological response of glutamine and glutamic acid supplemented broiler chickens to heat stress. European Poultry Science, 79, 1-12. DOI:10.1399/eps.2015.87

17. Ruiz-Jimenez, F., Gruber, E., Correa, M., \& Crespo, R. (2021). Comparison of portable and conventional laboratory analyzers for biochemical tests in chickens. Poultry Science, 100(2), 746-754. DOI:10.1016/j.psj.2020.11.060

18. Scanes, C.G. (2016). Biology of stress in poultry with emphasis on glucocorticoids and the heterophil to lymphocyte ratio. Poultry Science, 95(9), 2208-2215. DOI:10.3382/ps/pew137

19. Shevchuk, M., Stoyanovskyy, V., \& Kolomiiets, I. (2018). Technological stress in poultry. Scientific Messenger of LNU of Veterinary Medicine and Biotechnologies. Series: Veterinary Sciences, 20(88), 63-68. DOI:10.32718/nvlvet8811.

20. Vits, A., Weitzenburger, D., Hamann, H., \& Distl, O. (2005). Production, egg quality,bone strength, claw length, and keel bone deformities of laying hens housed infurnished cages with different group sizes. Poultry Science, 84, 1511-1519. DOI:10.1093/ps/84.10.1511

21. Weimer, S.L., Wideman, R.F., Scanes, C.G., Mauromoustakos, A., Christensen K.D., \& Vizzier-Thaxton, Y. (2018). An evaluation of methods for measuring stress in broiler chickens. Poultry Science, 97(10), 3381-3389. DOI:10.3382/ps/pey204

Osadcha Yuliia Vasylivna, Candidate of Agricultural Sciences, Associate Professor, National University of Life and Environmental Sciences of Ukraine (Kyiv, Ukraine)

\section{Serum biochemical profile and enzymes activity of hens under the influence of group size}

The results of the study of physiological changes in the body of hens due to changes in the group size of their based on the analysis of the parameters of serum clinical biochemistry are presented. To do this, in a modern complex for the eggs production formed 4 groups of hens, each of which was kept in a separate poultry house-analogue in area and equipment, equipped with 12-tier cage batteries, the size of the cages in which varied. The group size of hens in each cage of the 1 st group was 93 birds, the $2^{\text {nd }}-52$ birds, the $3^{\text {rd }}-17$ birds and $4^{\text {th }}-9$ birds. At the age of 52 weeks, 30 blood samples were taken from hens of each group and biochemical parameters and enzyme activity in its serum were determined. It was found that the decrease in the group size of hens for their content in the cage of multi-tiered batteries from 93 to 52 birds is accompanied only by an increase in lactate dehydrogenase activity by $14.4 \%$ within the physiological norm. With a decrease in the group size from 93 to 17 birds, there is an increase in glucose by $7.5 \%$ and phosphorus - by $89.2 \%$ within the physiological norm, a decrease in the calcium to phosphorus ratio by $30.0 \%$, an increase in aspartate aminotransferase activity by $17.7 \%$, alkaline phosphatase - by $94.4 \%$, gamma-glutamyltransferase - by $17.8 \%$ and lactate dehydrogenase - by $27.9 \%$. The decrease in the group size of hens from 93 to 9 birds is accompanied by the development of chronic stress, which was manifested by hyperglycemia with an increase in glucose by $61.3 \%$, creatinine - by $7.8 \%$, a decrease in calcium and phosphorus by $76.5 \%$, which is confirmed increasing the activity of alkaline phosphatase by $107.4 \%$, as well as aspartate aminotransferase - by $25.1 \%$, lactate dehydrogenase - by $59.6 \%$ and gamma-glutamyltransferase - by $25.7 \%$. Thus, the main effects of chronic stress caused by keeping hens in small groups are reflected in the biochemical parameters of their serum, namely in the increase of glucose, creatinine, enzyme activity, as well as the violation of calcium to phosphorus ratio.

Key words: laying hens, retention density, chronic stress, glucose, creatinine, enzyme activity.

Дата надходження до редакції: 03.09.2021 р. 